\title{
Accumulation of lactosylceramide and overexpression of a PSC833-resistant P-glycoprotein in multidrug-resistant human sarcoma cells
}

\author{
NASSERA AOUALI ${ }^{1}$, HASSAN EL BTAOURI $^{2}$, CHARLES DUMONTET $^{3}$, LAHCEN EDDABRA $^{2}$, \\ SOPHIE MALAGARIE-CAZENAVE ${ }^{4,5}$, CLAUDIE MADOULET ${ }^{2}$ and HAMID MORJANI ${ }^{2}$ \\ ${ }^{1}$ LHCE, Centre Hospitalier de Luxembourg, Luxembourg, Luxembourg; ${ }^{2}$ MEDyC Unité CNRS UMR6237, \\ UFR Pharmacie and UFR Sciences, Université de Reims, Reims; ${ }^{3}$ INSERM U590, UFR de Médecine, Lyon; \\ ${ }^{4}$ INSERM U858, Institut de Médecine Moléculaire de Rangueil, Université Paul-Sabatier, Toulouse, France
}

Received October 5, 2010; Accepted November 29, 2010

DOI: $10.3892 /$ or.2011.1180

\begin{abstract}
The selection pressure for resistance to chemotherapy is accompanied by the enhanced expression of $\mathrm{ABC}$ proteins and increased cellular glycosphingolipid content. Thus, a possible connection between glycosphingolipid metabolism and $\mathrm{ABC}$ proteins in drug resistance has been suggested. In the present study, we established two human multidrug-resistant (MDR) cell lines derived from MESSA sarcoma cells by culturing with increasing concentrations of doxorubicin (DX5 cells) or doxorubicin together with cyclosporin A (GARF cells). Both resistant cell lines overexpressed the MDRI gene and the wild-type P-glycoprotein at the same level. The cyclosporin derivative PSC833, a potent inhibitor of P-glycoprotein, sensitized DX5 but not GARF cells to the cytotoxic effects of daunorubicin. Moreover, PSC833 increased the nuclear accumulation of daunorubicin and the cellular accumulation of $\left[{ }^{3} \mathrm{H}\right]$ vinblastine in the DX5 but not in the GARF cells. The cellular incorporation of $\left[{ }^{3} \mathrm{H}\right]$-cyclosporin A was lower in DX5 cells compared to MESSA and GARF cells, which incorporated the same level of $\left[{ }^{3} \mathrm{H}\right]$-cyclosporin A. Sphingolipid analysis showed that the lactosylceramide level was 2.5- and 5-fold higher in DX5 and GARF cells, respectively, than in MESSA cells. Whereas the pharmacological inhibition of lactosylceramide synthesis was able to reverse only partially the resistance of GARF cells to daunorubicin without significant increase in nuclear
\end{abstract}

Correspondence to: Dr Hamid Morjani, MEDyC Unité CNRS UMR6237, UFR Pharmacie et UFR Sciences, Université de Reims, 51 rue Cognacq Jay, 51096 Reims, France

E-mail: hamid.morjani@univ-reims.fr

Present address: ${ }^{5}$ Department of Biochemistry and Molecular Biology, Faculty of Medicine, University of Alcala, Alcala de Henares, Madrid, Spain

Key words: multidrug resistance, lactosylceramide, P-glycoprotein, resistance to PSC833 accumulation of the drug, the same treatment before the cotreatment with PSC833 and daunorubicin increased the cytotoxic effect of daunorubicin and its nuclear accumulation. These data suggest a possible relationship between lactosylceramide levels and the resistance of P-glycoprotein to modulation by MDR modulators.

\section{Introduction}

Resistance to anti-cancer drugs is the main reason for treatment failure. Generally tumor cells initially respond well to chemotherapeutic agents. However, repeated drug administration provides pressure, which often results in the selection of drug-resistant cells and hence in incurable relapses. Cancer cells develop multiple mechanisms to evade drug cytotoxicity. One form of resistance is termed multidrug resistance (MDR) $(1,2)$ which is associated with a decrease in the intracellular concentration of the anti-cancer drug and consequently a reduction in the damage inflicted on the intracellular drug target(s). Other mechanisms of drug resistance which have been observed include alterations in gene expression in cellular targets $(3,4)$.

The altered pharmacology of drugs in MDR cancer cells is mediated by the overexpression of membrane proteins belonging to the ABC transporter family. P-glycoprotein (Pgp, $170 \mathrm{kDa}$ ) was the first one to be discovered and is encoded by the MDRl gene (2). Additional ABC transporters responsible for drug efflux include a protein known as the multidrug resistance-associated protein (MRP1) (5). MRP1 shares many substrates with Pgp, but exhibits slightly different substrate specificity. Moreover, the mechanism of drug efflux by MRP1 differs from that of Pgp. MRP1 is involved in the ATP-dependent transport of glutathione-S-conjugates (6). In addition to other transporters belonging to the MRP family which have been identified (7), a new ABC pump known as BCRP has been described which behaves as a half transporter (8). Many molecules can inhibit the activity of $\mathrm{ABC}$ transporters by blocking the binding site of the drug on the transporter and the efflux of the cytotoxic agent (9).

We, as well as others have shown that MDR cells which overexpress Pgp or MRP1 display a high level of glucosyl- 
ceramide (GlcCer) compared to drug-sensitive cells (10-12). The GlcCer synthase (GCS) inhibitor, threo-1-phenyl-2decanoylamino-3-morpholino-1-propanol (PDMP), is able to decrease the GlcCer level in MDR cells and partially restore their sensitivity to chemotherapeutic agents (13). The increase in the GlcCer level in resistant cells is the consequence of a higher activity of GCS (14) or an uncoupling between GCS and lactosylceramide (LacCer) synthase in the Golgi apparatus (15). The selection for resistance to anti-cancer drugs enhances ceramide metabolism through GCS in addition to the increased Pgp expression (16), whereas limiting the GCS activity downregulates the expression of Pgp (17). Therefore, it has been suggested that sphingolipids can modulate the MDR phenotype.

In the present study, we analyzed sphingolipid levels in two resistant sarcoma cell lines, DX5 and GARF cells, which overexpress Pgp. We also investigated the possible relationship between the LacCer level and the sensitivity of Pgp to MDR modulators.

\section{Materials and methods}

Cells. MESSA, a human uterine sarcoma cell line, was grown in monolayer. Resistant DX5 (18) and GARF cells were isolated by stepwise selection upon culture with increasing concentrations of doxorubicin (DOX) alone or together with cyclosporin A (CSA), respectively. Cells were grown in a 5\% $\mathrm{CO}_{2}$ atmosphere at $37^{\circ} \mathrm{C}$ in RPMI-1640 medium (Invitrogen, Paris, France) supplemented with $10 \%$ fetal calf serum (Invitrogen). DX5 and GARF cells were maintained continuously in the presence of $0.25 \mu \mathrm{M}$ DOX and $0.5 \mu \mathrm{M}$ DOX together with $2 \mu \mathrm{M}$ CSA, respectively.

Drugs and chemicals. DOX, daunorubicin (DNR), 3-[4,5dimethylthiazol-2-yl]-2,5 diphenyl tetrazolium bromide (MTT), PDMP, GlcCer, galactosylceramide (GalCer), and LacCer were purchased from Sigma (Saint Quentin Fallavier, France). $\left[{ }^{3} \mathrm{H}\right]$ Palmitic acid was obtained from GE Healthcare Europe GmbH (Saclay, France). Vinblastine (VBL) was obtained from Eli Lilly Co. (Indianapolis, IN). PSC833 was provided by Sandoz Pharmaceutical Corp. (Basel, Switzerland). $\left[{ }^{3} \mathrm{H}\right] \mathrm{CSA}$ and $\left[{ }^{3} \mathrm{H}\right] \mathrm{VBL}$ were purchased from GE Healthcare (Arlington Heights, IL). IntraPrep, the isotypes IgG1 and $\operatorname{IgG} 2 \mathrm{a}$, the primary antibody UIC2 and goat $\mathrm{F}\left(\mathrm{ab}^{\prime}\right) 2$ fragment mouse $\operatorname{IgG}(\mathrm{H}+\mathrm{L})$-FITC were obtained from Immunotech (Marseille, France). The primary antibodies, MRPm6 and BXP-34, were obtained from Alexis (San Diego, CA).

$m R N A$ analysis. Total RNA was extracted from $5 \times 10^{6}$ cells using the RNeasy mini kit and DNase I (Qiagen) according to the manufacturer's instructions. Total RNA $(1 \mu \mathrm{g})$ was reverse transcribed using random hexamers, MMLV reverse transcriptase and reaction buffer provided in the SuperScript First-Strand Synthesis System kit (Invitrogen). The volume of generated cDNA was adjusted to $40 \mu 1$ with diethylpyrocarbonate-treated water.

Real-time quantification of $M D R 1, M R P 1, M R P 2, M R P 3$ and $B C R P$ genes was performed on the ABI Prism 7000 Sequence Detection System (Applied Biosystems, Foster
City, CA, USA) using $5 \mu 1$ of diluted cDNA, $350 \mathrm{nM}$ of forward and reverse primers and SYBR-Green PCR Master Mix (Applied Biosystems, Warrington, UK) in a $25 \mu 1$ reaction volume under the following conditions: $95^{\circ} \mathrm{C}$ for $10 \mathrm{~min}$, followed by 40 cycles of $94^{\circ} \mathrm{C}$ for $45 \mathrm{sec}, 60^{\circ} \mathrm{C}$ for $45 \mathrm{sec}$, $72^{\circ} \mathrm{C}$ for $45 \mathrm{sec}$ and finally $72^{\circ} \mathrm{C}$ for $10 \mathrm{~min}$. Primers for $M D R 1$ (forward, AGGAAGCCAATGCCTATGACTTTA; and reverse, CAACTGGGCCCCTCTCTCTC), BCRP (forward, CAGGTCTGTTTCAATCTCACA; and reverse, TCCATATGGTGGAATGCTGAAG), MRP1 (forward, GAAGGCCATCGGACTCTTCA; and reverse, CAGCGCG GACACATGGT), MRP2 (forward, TGCAGCCTCCATAAC CATGAG; and reverse, GATGCCTGCCATTGGACCTA), and MRP3 (forward, CACACGGATCTTGACAGACA ATGA; and reverse, ACAGGGCACTCAGCTGTCTCA) were designed using the Primer Express software (Applied Biosystems). Primers for the TBP gene (forward, 5'-GCA CAGGAGCCAAGAGTGAA-3'; and reverse, 5'-TCACAGC TCCCCACCATGTT-3') were used according to a previously described method (19).

Quantification of an endogenous control gene (TBP for TATA box-binding protein) was performed to standardize the amount of cDNA added to each reaction. Data are presented as the relative expression of target genes using the comparative threshold cycle $(\mathrm{Ct})$ method (20). $\Delta \mathrm{Ct}$ is the difference in $\mathrm{Ct}$ values of the target gene and the housing gene, $T B P$, for sensitive and resistant cell lines. The relative expression of the target genes in DX5 and GARF cell lines compared to the MESSA cell line was expressed as $\Delta \Delta \mathrm{Ct}=\Delta \mathrm{Ct}$ (DX5 or GARF) - $\triangle \mathrm{Ct}$ (MESSA). The $\mathrm{N}$-fold expression of the target gene in DX5 or GARF cells was calculated as $\mathrm{N}=2^{-\Delta \Delta C t}$.

Flow cytometric analyses. For Pgp expression, $5 \times 10^{5}$ cells were fixed with solution 1 of IntraPrep lysing solution (Immunotech), and were washed and incubated for $45 \mathrm{~min}$ at room temperature in the presence of $5 \mu \mathrm{g} / \mathrm{ml}$ of either the monoclonal antibody UIC2 (Immunotech) that recognizes an external epitope of the Pgp or the control $\mathrm{IgG} 2 \mathrm{a}$ isotype (Immunotech). The cells were washed with ice-cold phosphate buffer solution containing $1 \%$ bovine serum albumin (Sigma), 5\% fetal calf serum, and were then incubated for $15 \mathrm{~min}$ at room temperature in the dark in the presence of goat $\mathrm{F}\left(\mathrm{ab}^{\prime}\right) 2$ fragment anti-mouse IgG-FITC at a dilution of 1:50. For the MRP1 and BCRP expression, the cells were fixed and permeabilized with solutions 1 and 2, respectively of IntraPrep lysing solution. The cells were then incubated for $45 \mathrm{~min}$ at room temperature with the monoclonal MRPm6 antibody $(2.5 \mu \mathrm{g} / \mathrm{ml})$ for the expression of MRP1 and BXP-34 $(5 \mu \mathrm{g} / \mathrm{ml})$ for the expression of BCRP (Coger, Paris, France) or the mouse IgG1 isotype as the control (Immunotech). Antibody binding was detected with the goat $\mathrm{F}\left(\mathrm{ab}^{\prime}\right) 2$ fragment anti-mouse IgG-FITC (Immunotech). Cells were analyzed using a Becton-Dickinson flow cytometer (Mountain View, CA, USA). Fluorescein was excited at $488 \mathrm{~nm}$ with an argon ion laser. Fluorescence emission was collected after passage through a 530-nm band pass filter. Data were collected and analyzed on a Hewlett-Packard model 310 computer interfaced with the FACScan. Protein expression was determined as the ratio of the mean fluorescence of the monoclonal antibodies, UIC2/IgG2a, MRPm6/IgG1, or BXP-34/IgG1 control. 
MTT cytotoxicity assay. Cytotoxicity experiments were performed using the MTT assay (21). The cells were plated into 96-well microtitre plates at 25,000 cells per $\mathrm{ml}$ and incubated for one day. The cells were then exposed to DNR $(0.01-100 \mu \mathrm{M})$ at $37^{\circ} \mathrm{C}$ with or without the modulator for $2 \mathrm{~h}$, washed and placed in drug-free medium for $72 \mathrm{~h}$. A solution of MTT $(20 \mu 1,2.5 \mathrm{mg} / \mathrm{ml})$ was added to each well for $4 \mathrm{~h}$. The medium was then discarded and $200 \mu \mathrm{l}$ of DMSO were added to each well. Optical densities were recorded at $540 \mathrm{~nm}$ using a Series 750 microplate reader (Cambridge Technology, Watertown, MA). The $50 \%$ inhibitory concentration $\left(\mathrm{IC}_{50}\right)$ was determined as the drug concentration which resulted in a $50 \%$ reduction in cell growth. Fold resistance was calculated by dividing the $\mathrm{IC}_{50}$ obtained for the resistant cells by the $\mathrm{IC}_{50}$ obtained for the sensitive ones.

Determination of nuclear accumulation of DNR. Confocal laser microspectrofluorometry was used for the acquisition and analysis of emission spectra from a confocal section within an isolated living cell. The nuclear accumulation of DNR was monitored through its fluorescence emission spectra. Cells were placed in petri dish $24 \mathrm{~h}$ prior to the experiments. After treatment, the cells were washed free of drugs with PBS at $4^{\circ} \mathrm{C}$ and placed in medium without phenol red at $4^{\circ} \mathrm{C}$ (Sigma). The laser $(457.9 \mathrm{~nm}, 4 \mu \mathrm{W})$ was focused for $1 \mathrm{sec}$ on a nucleus to obtain fluorescence emission spectra. The emission arising from the nucleus can be expressed as the sum of spectral contributions from the free and DNAbound drug models at known concentrations, and nuclear autofluorescence. Each of these contributions had a characteristic spectral shape. In addition, the model spectra showed a 40-fold quenching factor for the DNA-DNR bound form compared to the free form. These spectral contributions lead to the concentrations of free and DNA-bound DNR (22). The sum of free and bound drug concentrations gave the total nuclear concentration of DNR. For each condition, nuclear spectra (one per cell) of at least 50 cells per experiment were recorded for three independent experiments.

Cellular accumulation of radiolabelled CSA and VBL. The intracellular accumulation of $\left[{ }^{3} \mathrm{H}\right] \mathrm{CSA}$ was measured at two concentrations, $250 \mathrm{nM}$ or $750 \mathrm{nM}$. The cells $\left(10^{6}\right.$ cells $\left./ \mathrm{ml}\right)$ were incubated with CSA for $1 \mathrm{~h}$ in Falcon tissue culture plates. The intracellular accumulation of $\left[{ }^{3} \mathrm{H}\right] \mathrm{VBL}$ was determined in the presence or absence of PSC833, using $10^{6}$ cells $/ \mathrm{ml}$ incubated with $1 \mu \mathrm{M}\left[{ }^{3} \mathrm{H}\right] \mathrm{VBL}$ for $1 \mathrm{~h}$. All values were normalized to the protein content as previously described (23).

Sphingolipid analysis. The sphingolipid content was analyzed as described previously (24). Briefly, the cells were seeded in $175 \mathrm{~cm}^{2}$ flasks with medium. After $24 \mathrm{~h}$, the medium was removed and replaced by complete medium containing $1 \mu \mathrm{Ci} / \mathrm{ml}{ }^{3} \mathrm{H}$-palmitic acid with or without PDMP for $24 \mathrm{~h}$. Cells were washed twice with PBS, scraped and centrifuged at 1,000 rpm for $7 \mathrm{~min}$. For lipid extraction, cell pellets were homogenized in $9 \% \mathrm{NaCl}$ solution of $10^{7}$ cells per $\mathrm{ml}$. Then, $3.75 \mathrm{ml}$ of chloroform/methanol $(2: 1 \mathrm{v} / \mathrm{v})$, $1.25 \mathrm{ml}$ of chloroform and $1.25 \mathrm{ml} \mathrm{H}_{2} \mathrm{O}$, were added. After sonication and centrifugation at 1,000 rpm for $5 \mathrm{~min}$, the organic phase containing total lipids was removed and dried under a stream of nitrogen. Total lipids were separated into polar and neutral fractions by solid-phase extraction as follows: Total lipids were dissolved in $100 \mu \mathrm{l}$ chloroform and applied onto a $200 \mathrm{mg}$ silica (G60) column. Neutral lipids were eluted with $8 \mathrm{ml}$ chloroform/acetic acid (100:1, v/v). Polar lipids were eluted with $10 \mathrm{ml}$ acetone/methanol (19:1, $\mathrm{v} / \mathrm{v}$ ) and evaporated to dryness. In order to analyze different glycolipids, dried polar lipids were then re-suspended in $100 \mu \mathrm{l}$ chloroform/methanol $(2: 1 \mathrm{v} / \mathrm{v})$ and separated by thinlayer chromatography (TLC, silica gel G60) using a solvent system of chloroform/methanol/triethylamine/water (30:35:35:6, v/v). Sphingomyelin was resolved by highperformance TLC silica-gel 60 plates using a mobile phase consisting of chloroform/methanol/acetic acid/formic acid/ water $(35: 15: 6: 2: 1, \mathrm{v} / \mathrm{v})$. Standard commercial glycolipids and sphingomyelin were also chromatographed. Spots were visualized by $\mathrm{H}_{2} \mathrm{SO}_{4}$ vapour after heating for $20 \mathrm{~min}$ at $180^{\circ} \mathrm{C}$. Glycolipids were scraped into $2 \mathrm{ml}$ of scintillation liquid and radioactivity was quantified by liquid scintillation counting. Quantification of sphingomyelin was achieved following densitometric analysis.

Statistical analysis. Values are presented as the means \pm SD. Mean values were considered to be significantly different using an appropriate unpaired t-test.

\section{Results}

DX5 and GARF cells overexpress MDRI and Pgp. In order to evaluate the level of transcription of multidrug-resistance genes in DX5 and GARF cell lines, real-time quantification assays were performed and $\mathrm{Ct}$ was determined. Whereas there was no significant difference in $M R P 1, M R P 2$ and $M R P 3$ gene expression between the control, DX5 and GARF cells, MDR1 was strongly overexpressed in DX5 and GARF cell lines. The expression of $B C R P$ was increased only in GARF cells (Table I).

The level of Pgp expression was determined by flow cytometry using the UIC2 antibody. As expected, while MESSA cells exhibited very low to undetectable levels of Pgp with a normalized level of 1.04, DX5 and GARF cells overexpressed Pgp (Table II). No mutation in Pgp was detected in the GARF cells and protein glycosylation was similar to that of wild-type Pgp (data not shown). Similar measurements were performed using MRPm6 and BXP34 antibodies raised against MRP1 and BCRP and no significant overexpression of these proteins was observed in the two resistant cell lines.

PSC833 overcomes resistance to DNR in DX5 but not in GARF cells. The cells were treated for $2 \mathrm{~h}$ with DNR (0.01$100 \mu \mathrm{M})$ in the presence or absence of $2 \mu \mathrm{M}$ of the MDR modulator, PSC833. The cells were then washed and placed in drug-free medium for $72 \mathrm{~h}$ prior to the cytotoxicity assays. The $\mathrm{IC}_{50}$ of DNR was $1.5,18$ and $90 \mu \mathrm{M}$ in MESSA, DX5 and GARF cells, respectively (Table III). Thus, DX5 and GARF cells were 12- and 60-fold resistant to DNR compared to MESSA cells, respectively. After PSC833 and DNR cotreatment, the $\mathrm{IC}_{50}$ of DNR decreased in DX5 cells to a value 
Table I. Relative mRNA expression levels of $M D R 1, M R P 1, M R P 2, M R P 3$ and $B C R P$ as estimated by real-time RT-PCR in MESSA, DX5 and GARF cells.

\begin{tabular}{|c|c|c|c|c|c|c|c|c|}
\hline \multirow[b]{2}{*}{ Gene } & \multicolumn{2}{|c|}{ MESSA } & \multicolumn{3}{|c|}{ DX5 } & \multicolumn{3}{|c|}{ GARF } \\
\hline & $\mathrm{Ct}$ & $\Delta \mathrm{Ct}$ & $\mathrm{Ct}$ & $\Delta \mathrm{Ct}$ & $\mathrm{N}$ & $\mathrm{Ct}$ & $\Delta \mathrm{Ct}$ & $\mathrm{N}$ \\
\hline TBP & 22.63 & - & 22.72 & - & - & 22.61 & - & - \\
\hline$M R P 1$ & 23.37 & 0.74 & 23.76 & 1.04 & 0.81 & 22.36 & -0.25 & 1.99 \\
\hline$M R P 2$ & 19.47 & -3.16 & 21.75 & -0.97 & 0.22 & 21.67 & -0.94 & 0.21 \\
\hline$M R P 3$ & 26.10 & 3.47 & 28.41 & 5.69 & 0.21 & 28.27 & 5.66 & 0.22 \\
\hline$M D R 1$ & 33.07 & 10.44 & 17.18 & -5.54 & 64635 & 17.27 & -5.34 & 56267 \\
\hline$B C R P$ & 27.30 & 4.67 & 27.26 & 4.54 & 1.09 & 24.36 & 1.75 & 7.57 \\
\hline
\end{tabular}

The fold change of target gene expression in DX5 and GARF cell lines, normalized to TBP $(\Delta \mathrm{Ct})$ and compared to MESSA cells which were used as the calibrators $\left(\Delta \Delta \mathrm{Ct}\right.$ ), was determined by the formula: $\mathrm{N}=2^{-\Delta \Delta \mathrm{Ct}}$. Data are the means of three experiments.

Table II. Relative protein expression level assessed by flow cytometry.

\begin{tabular}{lccc}
\hline Cell line & Pgp & MRP1 & BCRP \\
\hline MESSA & $1.04 \pm 0.2$ & $0.82 \pm 0.2$ & $0.9 \pm 0.15$ \\
DX5 & $5.3 \pm 0.15$ & $1.35 \pm 0.25$ & $0.7 \pm 0.28$ \\
GARF & $5.29 \pm 0.5$ & $1.2 \pm 0.2$ & $1.25 \pm 0.2$ \\
\hline
\end{tabular}

Data are expressed as the ratio of the arithmetic mean fluorescence of UIC2/IgG2a, MRPm6/IgG1, or BXP34/IgG1 control. Data are the means of three experiments.

of $1.5 \mu \mathrm{M}$ and thus led to an almost complete reversion of resistance. However, PSC833 did not sensitize GARF cells to the cytotoxic effect of DNR.

PSC833 increases nuclear accumulation of DNR in DX5 cells but not in GARF cells. Following treatment with $1 \mu \mathrm{M}$ DNR for $2 \mathrm{~h}$ in the presence or absence of $2 \mu \mathrm{M}$ PSC 833 , the cells were washed and analyzed by microspectrofluorometry. In the absence of PSC833, the nuclear concentration of DNR was reduced by $\sim 60 \%$ in DX5 and GARF cells. When DX5 cells were treated with PSC833, the nuclear accumulation of DNR almost doubled. In GARF cells however, PSC833 did not increase the nuclear accumulation of DNR (Fig. 1A).

PSC833 increases $\left[{ }^{3} \mathrm{H}\right]$ VBL accumulation in DX5 cells but not in GARF cells. Sarcoma cells were incubated with $1 \mu \mathrm{M}$ $\left[{ }^{3} \mathrm{H}\right] \mathrm{VBL}$ for $1 \mathrm{~h}$ in the presence or absence of $2 \mu \mathrm{M}$ PSC833. The VBL accumulation in MESSA cells was 5-6 fold higher than that in DX5 and GARF cells (Fig. 2A). When resistant cells were treated with PSC833, $\left[{ }^{3} \mathrm{H}\right] \mathrm{VBL}$ accumulation was significantly increased in DX5 cells but not in GARF cells.

Similar accumulation of $\left[{ }^{3} H\right] C S A$ in MESSA and GARF cells. As GARF cells did not respond to PSC833 (Figs. 1A and $2 \mathrm{~A}$ ), we examined whether GARF cells have an impairment of cyclosporin incorporation. The cells were incubated for $1 \mathrm{~h}$ with $\left[{ }^{3} \mathrm{H}\right] \mathrm{CSA}$ at two different concentrations (250 and $750 \mathrm{nM})$. The cellular accumulation of CSA in MESSA cells was 2-fold higher than that in DX5 cells (Fig. 2B).

Table III. Effect of PDMP on the cytotoxic effect of DNR with or without PSC833 in MESSA, DX5 and GARF cells.

\begin{tabular}{|c|c|c|c|c|c|c|c|c|}
\hline & \multicolumn{2}{|c|}{ DNR } & \multicolumn{2}{|c|}{$\mathrm{DNR}+\mathrm{PSC} 833$} & \multicolumn{2}{|c|}{$\mathrm{DNR}+\mathrm{PDMP}$} & \multicolumn{2}{|c|}{$\begin{array}{c}\text { DNR + PSC833 } \\
\text { after PDMP } \\
\text { pre-treatment }\end{array}$} \\
\hline & $\mathrm{IC}_{50}$ & FR & $\mathrm{IC}_{50}$ & FR & $\mathrm{IC}_{50}$ & FR & $\mathrm{IC}_{50}$ & FR \\
\hline MESSA & 1.5 & & 0.8 & & 1.5 & & 1.1 & \\
\hline DX5 & 18 & 12 & 1.5 & 1.88 & 12 & 8 & 1.5 & 1.36 \\
\hline GARF & 90 & 60 & 90 & 60 & 56 & 37.30 & 3 & 2.73 \\
\hline
\end{tabular}

Cells were treated or not for $24 \mathrm{~h}$ with $20 \mu \mathrm{M}$ PDMP prior to treatment with DNR $(0.01-100 \mu \mathrm{M})$ in the presence or absence of $2 \mu \mathrm{M}$ PSC833 for $2 \mathrm{~h}$. The cells were then washed and incubated in medium for $72 \mathrm{~h}$ prior to the MTT assay measurements. The IC $\mathrm{I}_{50}$ is the DNR concentration which induces $50 \%$ growth inhibition. $\mathrm{FR}$ (fold resistance) $=\mathrm{IC}_{50}$ of DNR in resistant cells $/ \mathrm{IC}_{50}$ of DNR in sensitive cells. 


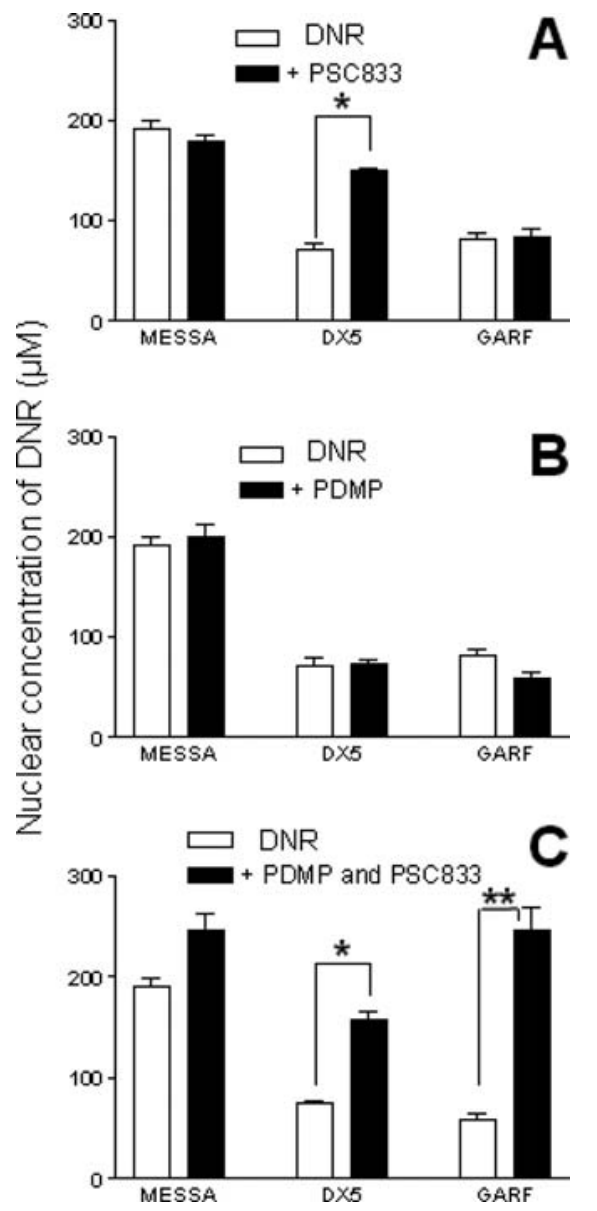

Figure 1. Effect of PDMP pre-treatment with or without PSC833 on the nuclear accumulation of DNR in MESSA, DX5 and GARF cells. Cells were pre-treated (B and C) or not (A) with $20 \mu \mathrm{M}$ PDMP for $24 \mathrm{~h}$. Then, the cells were washed and treated with $1 \mu \mathrm{M}$ DNR for $2 \mathrm{~h}$ in the presence (A and C) or absence (B) of $2 \mu \mathrm{M}$ PSC833 prior to microspectrofluorometric analysis. Data are expressed as the means $\pm \mathrm{SD}$ of three experiments. ${ }^{*} \mathrm{p}<0.05$, ${ }^{* *} \mathrm{p}<0.02$.

However, CSA accumulation in GARF cells was similar to that of drug-sensitive cells.

High level of lactosylceramide in GARF cells. Intracellular levels of GlcCer, GalCer and LacCer were determined after metabolic labelling with $\left[{ }^{3} \mathrm{H}\right]$ palmitic acid. The amounts of glycolipid-incorporated radioactivity were normalized to the total amounts of protein (dpm/mg of protein). As shown in Table IV, the LacCer level in DX5 and GARF cells was 2.5and 5-fold higher, respectively, than that in MESSA cells. There was no significant change in cellular sphingomyelin content, determined as the control, when the three cell lines were compared. After 24-h treatment of DX5 and GARF cells with $20 \mu \mathrm{M}$ of PDMP, LacCer biosynthesis was strongly inhibited as evidenced by a $95 \%$ decrease in LacCer content (data not shown).

Effects of PDMP on the resistance to DNR and its nuclear accumulation in DX5 and GARF cells. We then wished to investigate the effect of the GCS inhibitor, PDMP, at subtoxic concentrations on the resistance to DNR in sarcoma
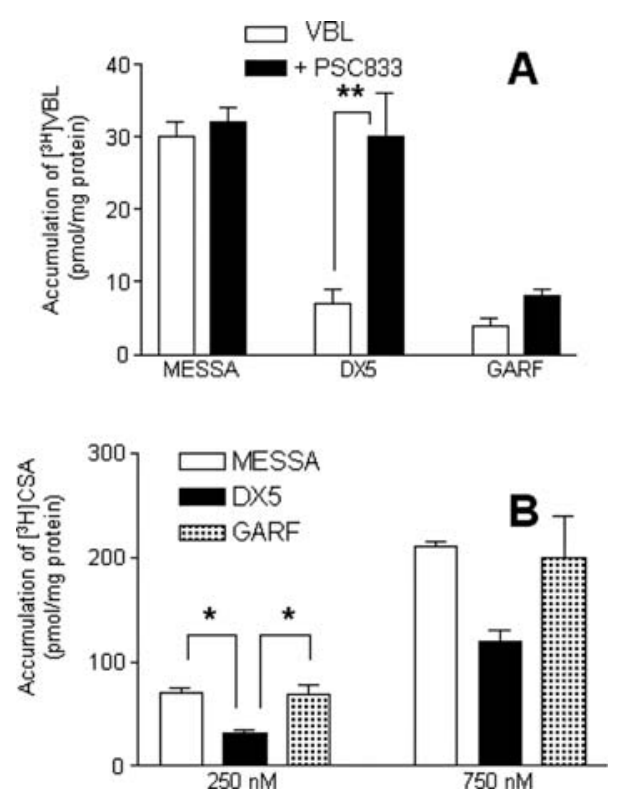

Figure 2. (A) Effect of PSC833 on the cellular accumulation of $\left[{ }^{3} \mathrm{H}\right] \mathrm{VBL}$ in MESSA, DX5 and GARF cells. The cellular accumulation of VBL was measured after 1 -h treatment with $1 \mu \mathrm{M}\left[{ }^{3} \mathrm{H}\right] \mathrm{VBL}$ in the presence or absence of $2 \mu \mathrm{M}$ PSC833. Data are the means of three experiments. (B) Cellular accumulation of $\left[{ }^{3} \mathrm{H}\right] \mathrm{CSA}$ in MESSA, DX5 and GARF cells. Cells were treated with either 250 or $750 \mathrm{nM}\left[{ }^{3} \mathrm{H}\right] \mathrm{CSA}$ for $1 \mathrm{~h}$. Data are expressed as the means \pm SD of three experiments. ${ }^{*} \mathrm{p}<0.05,{ }^{* *} \mathrm{p}<0.02$. Statistical significance for $\left[{ }^{3} \mathrm{H}\right] \mathrm{CSA}$ treatment at $750 \mathrm{nM}$ is the same as that at $250 \mathrm{nM}$.

cells. The first step was to determine the $\mathrm{IC}_{10}$ of PDMP. Cells were treated for $24 \mathrm{~h}$ with PDMP at various concentrations $(0.1$ to $50 \mu \mathrm{M})$, then washed and further incubated for $72 \mathrm{~h}$. The concentration which induced $<10 \%$ growth inhibition was $20 \mu \mathrm{M}$. For DNR and PDMP association studies, the cells were incubated $24 \mathrm{~h}$ with $20 \mu \mathrm{M}$ PDMP and then treated with DNR for $2 \mathrm{~h}$ before washing and further incubation for 72 h. PDMP pre-treatment modestly increased DNR cytotoxicity in DX5 and GARF cells (Table III). The $\mathrm{IC}_{50}$ of DNR decreased from 18 and 90 to 12 and $56 \mu \mathrm{M}$ in DX5 and GARF cells, respectively. In this case, the residual fold resistance decreased from 12 and 60 to 8 and 37.3. The PDMP treatment did not increase the nuclear accumulation of DNR in DX5 and GARF cells (Fig. 1B).

GCS inhibition sensitizes GARF cells to the modulatory effect of PSC833. We then tested the effect of a combined treatment with $20 \mu \mathrm{M}$ PDMP and $2 \mu \mathrm{M}$ PSC833 on the sensitivity to DNR. Under these conditions, DNR cytotoxicity was significantly increased in GARF cells (Table III ). The residual fold resistance dropped from 60 to 2.73. PDMP pre-treatment followed by the addition of PSC833, also increased the nuclear accumulation of DNR in GARF cells (Fig. 1C). The nuclear accumulation of DNR increased 4-fold and reached the level found in drug-sensitive cells. It is important to note that in the absence of PDMP, PSC833 was unable to increase the nuclear accumulation of DNR in GARF cells (Fig. 1A). In DX5 cells, PDMP pre-treatment followed by the addition of PSC833, did not increase the nuclear accumulation of DNR compared to the PSC833 treatment alone (Fig. 1A and C). 
Table IV. Incorporation of $\left[{ }^{3} \mathrm{H}\right]$ palmitic acid into neutral glycosphingolipids.

\begin{tabular}{llll}
\hline & MESSA & \multicolumn{1}{c}{ DX5 } & \multicolumn{1}{c}{ GARF } \\
\hline GlcCer & $2939 \pm 1151$ & $2517 \pm 761$ & $3133 \pm 1154$ \\
GalCer & $1944 \pm 677$ & $1549 \pm 358$ & $1422 \pm 525$ \\
LacCer & $1826 \pm 677$ & $4725 \pm 1088^{\mathrm{a}}$ & $9130 \pm 1911^{\mathrm{b}}$ \\
Sphingomyelin & $0.495 \pm 0.12$ & $0.512 \pm 0.08$ & $0.536 \pm 0.23$ \\
\hline
\end{tabular}

Cells were labeled with $1 \mu \mathrm{Ci} / \mathrm{ml}\left[{ }^{3} \mathrm{H}\right]$ palmitic acid for $24 \mathrm{~h}$ and lipids were extracted and separated by chromatography. Bands corresponding to each of the glycolipids were scraped and the radioactivity was quantified by liquid scintillation counting. The amounts of glycolipid-incorporated radioactivity were normalized to the total protein amounts (dpm/mg protein). Quantification of total sphingomyelin was achieved following densitometric analysis (AU/mg protein). Data are expressed as the means \pm SD of triplicate determinations from three experiments. ${ }^{\mathrm{a}} \mathrm{p}<0.02,{ }^{\mathrm{b}} \mathrm{p}<0.01$.

\section{Discussion}

Multidrug resistance occurs when cancer cells resist chemotherapy by removing a broad range of lipophilic drugs. These cells express high levels of the MDR transporters and in particular, Pgp. Certain molecules such as cyclosporin A and PSC833 have been described to potently inhibit Pgp $(9,25)$. In the present study, we show that Pgp is overexpressed in MDR human sarcoma GARF cells that have been selected in the presence of DOX and CSA. Moreover, in contrast to DX5 cells, GARF cells were not sensitized to DNR in the presence of PSC833. In order to examine whether this property was specific to anthracyclines, the effect of PSC833 on the cytotoxicity of VBL was tested. GARF cells were not sensitized to VBL in the presence of PSC833 (data not shown).

We first hypothesized that in GARF cells, the affinity of CSA to Pgp is lower than it is in DX5 cells due to a mutation of the protein, as this has already been demonstrated in another cellular model (26). The cellular accumulation of $\left[{ }^{3} \mathrm{H}\right] \mathrm{CSA}$ in GARF cells was similar to that in MESSA cells and significantly higher to that in DX5 cells. However, (i) no mutation in Pgp was observed, and (ii) protein glycosylation was similar to that of wild-type Pgp (data not shown). It is important to note that Pgp expression in GARF cells was similar to that in DX5 cells.

We then tested another pathway, namely the involvement of ceramide metabolism. As a matter of fact, the selection for resistance to anti-cancer drugs elevates cellular glycosphingolipid levels through GCS in addition to enhanced Pgp expression (16). Conversely, the inhibition of GCS downregulates the expression of Pgp (17). In GARF cells, the overexpression of Pgp was accompanied by an increased LacCer level. Plo et al have shown that treatment with PDMP results in increased rhodamine 123 retention and potent chemosensitization of Pgp-expressing leukemic cells (27). In the above study, PDMP increased ceramide levels but reduced ganglioside levels. They also demonstrated that gangliosides were able to modulate Pgp phosphorylation, and they suggested that ganglioside depletion accounts for the
PDMP-mediated MDR reversal effect. In our study, the inhibition of GCS by PDMP induced a decrease in the LacCer level but did not significantly increase the nuclear accumulation of DNR in DX5 and GARF cells. This suggests that the relative sensitization of DX5 and GARF cells to DNR by PDMP is possibly due to ceramide accumulation. However, the combined treatment of GARF cells with PDMP and PSC833 resulted in a significant reversion of resistance to DNR. This was accompanied by a significant increase in nuclear accumulation of DNR.

Over the years, distinct membrane structures known as rafts containing LacCer have been described, which play an important role in the function of many membrane proteins and signal transduction $(28,29)$. Hinrichs et al have shown that Pgp is enriched in raft structures in selected drugresistant cells (30). As sphingolipid levels play a structural role in microdomain organization (31) and in particular, LacCer, which is able to increase the resistance of rafts to detergents (32), a possible relationship between the LacCer level and the modulation of Pgp can be speculated. However, a direct cause-effect relationship between the two phenomena needs to be demonstrated. Further investigation is required in order to ascertain whether the affinity of Pgp for PSC833 can be modulated by GCS inhibition.

\section{Acknowledgements}

This study was supported by a grant from the Ligue Nationale Contre le Cancer to H.M. N.A. was the recipient of financial support from the Fondation pour la Recherche Médicale (FRM).

\section{References}

1. Gottesman MM and Ling V: The molecular basis of multidrug resistance in cancer: the early years of P-glycoprotein research. FEBS Lett 580: 998-1009, 2006.

2. Gottesman MM and Pastan I: Biochemistry of multidrug resistance mediated by the multidrug transporter. Annu Rev Biochem 62: 385-427, 1993.

3. Friche E, Danks MK, Schmidt CA and Beck WT: Decreased DNA topoisomerase II in daunorubicin-resistant Ehrlich ascites tumor cells. Cancer Res 51: 4213-4218, 1991.

4. Chrencik JE, Staker BL, Burgin AB, Pourquier P, Pommier Y, Stewart L and Redinbo MR: Mechanisms of camptothecin resistance by human topoisomerase I mutations. J Mol Biol 339: 773-784, 2004

5. Cole SP, Bhardwaj G, Gerlach JH, Mackie JE, Grant CE, Almquist KC, Stewart AJ, Kurz EU, Duncan AM and Deeley RG: Overexpression of a transporter gene in a multidrug-resistant human lung cancer cell line. Science 258: 1650-1654, 1992.

6. Leier I, Jedlitschky G, Buchholz U, Cole SP, Deeley RG and Keppler D: The MRP gene encodes an ATP-dependent export pump for leukotriene $\mathrm{C} 4$ and structurally related conjugates. J Biol Chem 269: 27807-27810, 1994.

7. Kool M, de Haas M, Scheffer GL, Scheper RJ, van Eijk MJ, Juijn JA, Baas F and Borst P: Analysis of expression of cMOAT (MRP2), MRP3, MRP4, and MRP5, homologues of the multidrug resistance-associated protein gene (MRP1), in human cancer cell lines. Cancer Res 57: 3537-3547, 1997.

8. Doyle LA, Yang W, Abruzzo LV, Krogmann T, Gao Y, Rishi AK and Ross DD: A multidrug resistance transporter from human MCF-7 breast cancer cells. Proc Natl Acad Sci USA 95: 15665-15670, 1998.

9. Ozben T: Mechanisms and strategies to overcome multiple drug resistance in cancer. FEBS Lett 580: 2903-2909, 2006.

10. Lavie Y, Cao H, Bursten SL, Giuliano AE and Cabot MC: Accumulation of glucosylceramides in multidrug-resistant cancer cells. J Biol Chem 271: 19530-19536, 1996. 
11. Morjani H, Aouali N, Belhoussine R, Veldman RJ, Levade T and Manfait M: Elevation of glucosylceramide in multidrugresistant cancer cells and accumulation in cytoplasmic droplets. Int J Cancer 94: 157-165, 2001.

12. Kok JW, Veldman RJ, Klappe K, Koning H, Filipeanu CM and Muller M: Differential expression of sphingolipids in MRP1 overexpressing HT29 cells. Int J Cancer 87: 172-178, 2000.

13. Lavie Y, Cao H, Volner A, Lucci A, Han TY, Geffen V, Giuliano AE and Cabot MC: Agents that reverse multidrug resistance, tamoxifen, verapamil, and cyclosporin A, block glycosphingolipid metabolism by inhibiting ceramide glycosylation in human cancer cells. J Biol Chem 272: 1682-1687, 1997.

14. Liu YY, Han TY, Giuliano AE and Cabot MC: Expression of glucosylceramide synthase, converting ceramide to glucosylceramide, confers adriamycin resistance in human breast cancer cells. J Biol Chem 274: 1140-1146, 1999.

15. Veldman RJ, Klappe K, Hinrichs J, Hummel I, van der Schaaf G, Sietsma H and Kok JW: Altered sphingolipid metabolism in multidrug-resistant ovarian cancer cells is due to uncoupling of glycolipid biosynthesis in the Golgi apparatus. FASEB J 16: 1111-1113, 2002.

16. Gouaze V, Yu JY, Bleicher RJ, Han TY, Liu YY, Wang H, Gottesman MM, Bitterman A, Giuliano AE and Cabot MC: Overexpression of glucosylceramide synthase and P-glycoprotein in cancer cells selected for resistance to natural product chemotherapy. Mol Cancer Ther 3: 633-639, 2004.

17. Gouaze V, Liu YY, Prickett CS, Yu JY, Giuliano AE and Cabot MC: Glucosylceramide synthase blockade downregulates P-glycoprotein and resensitizes multidrug-resistant breast cancer cells to anticancer drugs. Cancer Res 65: 3861-3867, 2005.

18. Harker WG and Sikic BI: Multidrug (pleiotropic) resistance in doxorubicin-selected variants of the human sarcoma cell line MES-SA. Cancer Res 45: 4091-4096, 1985.

19. Lossos IS, Czerwinski DK, Wechser MA and Levy R: Optimization of quantitative real-time RT-PCR parameters for the study of lymphoid malignancies. Leukemia 17: 789-795, 2003.

20. Ginzinger DG: Gene quantification using real-time quantitative PCR: an emerging technology hits the mainstream. Exp Hematol 30: 503-512, 2002

21. Alley MC, Scudiero DA, Monks A, Hursey ML, Czerwinski MJ, Fine DL, Abbott BJ, Mayo JG, Shoemaker RH and Boyd MR: Feasibility of drug screening with panels of human tumor cell lines using a microculture tetrazolium assay. Cancer Res 48 : 589-601, 1988
22. Gigli M, Doglia SM, Millot JM, Valentini L and Manfait M: Quantitative study of doxorubicin in living cell nuclei by microspectrofluorometry. Biochim Biophys Acta 950: 13-20, 1988.

23. Beketic-Oreskovic L, Duran GE, Chen G, Dumontet C and Sikic BI: Decreased mutation rate for cellular resistance to doxorubicin and suppression of mdr1 gene activation by the cyclosporin PSC 833. J Natl Cancer Inst 87: 1593-1602, 1995.

24. Leray C, Pelletier X. Hemmendinger S and Cazenave JP: Thinlayer chromatography of human platelet phospholipids with fatty acid analysis. J Chromatogr 420: 411-416, 1987.

25. Aouali N, Eddabra L, Macadre J and Morjani H: Immunosuppressors and reversion of multidrug-resistance. Crit Rev Oncol Hematol 56: 61-70, 2005.

26. Chen G, Duran GE, Steger KA, Lacayo NJ, Jaffrezou JP, Dumontet C and Sikic BI: Multidrug-resistant human sarcoma cells with a mutant $\mathrm{P}$-glycoprotein, altered phenotype, and resistance to cyclosporins. J Biol Chem 272: 5974-5982, 1997.

27. Plo I, Lehne G, Beckstrom KJ, Maestre N, Bettaieb A, Laurent G and Lautier D: Influence of ceramide metabolism on Pglycoprotein function in immature acute myeloid leukemia KG1a cells. Mol Pharmacol 62: 304-312, 2002.

28. Degroote S, Wolthoorn J and van Meer G: The cell biology of glycosphingolipids. Semin Cell Dev Biol 15: 375-387, 2004.

29. Sprong H, van der Sluijs $P$ and van Meer G: How proteins move lipids and lipids move proteins. Nat Rev Mol Cell Biol 2: 504-513, 2001.

30. Hinrichs JW, Klappe K, Hummel I and Kok JW: ATP-binding cassette transporters are enriched in non-caveolar detergentinsoluble glycosphingolipid-enriched membrane domains (DIGs) in human multidrug-resistant cancer cells. J Biol Chem 279: 5734-5738, 2004.

31. Klappe K, Hinrichs JW, Kroesen BJ, Sietsma H and Kok JW: MRP1 and glucosylceramide are coordinately over expressed and enriched in rafts during multidrug resistance acquisition in colon cancer cells. Int J Cancer 110: 511-522, 2004.

32. Parkin ET, Turner AJ and Hooper NM: Differential effects of glycosphingolipids on the detergent-insolubility of the glycosylphosphatidylinositol-anchored membrane dipeptidase Biochem J 358: 209-216, 2001. 